\title{
Consideraciones sobre las actuaciones previas y su incidencia en el procedimiento administrativo sancionador y en las garantías del administrado
}

\author{
Encarnación Montoya Martín'
}

Sumario: INTRODUCCIÓN. I. NATURALEZA Y FINALIDAD DE LAS ACTUACIONES PREVIAS: 1. No forman parte del procedimiento. 2. Clases: Actuaciones previas con conocimiento del interesado e información reservada. 3. Carácter facultativo o potestativo. II. LAS GARANTÍAS APLICABLES A LAS ACTUACIONES PREVIAS. 1. La doctrina del TC. 1.1. El derecho a no declarar contra sí mismo y a no confesarse culpable como garantías instrumentales del genérico derecho de defensa. 1.2. Modulación derivada de la relación de sujeción especial. 2. La doctrina de los Tribunales ordinarios. 2.1. No resultan aplicables las garantías propias del procedimiento administrativo sancionador. 2.2. Los controles técnicos previos se asimilan a las actuaciones previas. 2.3. Incidencia de informes y averiguaciones efectuados durante el trámite de actuaciones previas en el posterior procedimiento sancionador. III. INCIDENCIA DE LAS ACTUACIONES PREVIAS SOBRE LA PRESCRIPCIÓN DE LA INFRACCIÓN Y SOBRE LA CADUCIDAD DEL EXPEDIENTE SANCIONADOR. 1. Actuaciones previas y prescripción de la infracción. 2. Actuaciones previas y caducidad del procedimiento sancionador. IV. CONCLUSIÓN.

\section{INTRODUCCIÓN}

Desde la sentencia 18/1981, de 18 de junio, el TC ha proclamado, siguiendo la doctrina del Tribunal Europeo de Derechos Humanos (caso Albert-le Compte TEDH 1983,11), no sólo la aplicabilidad a las sanciones administrativas de los principios sustantivos derivados del art. 25.1CE, considerando que "Ios principios inspiradores del orden penal son de aplicación con ciertos matices al Derecho administrativo sancionador, dado que ambos son manifestaciones del ordenamiento punitivo del Estado"

1 Profesora Titular de Derecho Administrativo. Universidad de Sevilla. 
(F. 2), sino que también ha proyectado sobre las actuaciones dirigidas a ejercer las potestades sancionadoras de la Administración las garantías procedimentales ínsitas en el art. 24 CE, en sus dos apartados, no mediante una aplicación literal, sino "en la medida necesaria para preservar los valores esenciales que se encuentran en la base del precepto, y la seguridad jurídica que garantiza el art. 9 de la CE”. No obstante, ha precisado también que no se trata de una aplicación literal, dadas las diferencias entre uno y otro orden sancionador, sino "con el alcance que requiere la finalidad que justifica la previsión constitucional".

Esa operación de traslación de las garantías del art. 24 CE al procedimiento administrativo sancionador viene condicionada a que se trate de garantías que resulten compatibles con la naturaleza de dicho procedimiento. Se ha ido elaborando progresivamente en numerosas resoluciones una consolidada doctrina constitucional, en la que se citan como aplicables, sin ánimo de exhaustividad, el derecho de defensa, que proscribe cualquier indefensión; el derecho a ser informado de la acusación, con la ineludible consecuencia de la inalterabilidad de los hechos imputados; el derecho a la presunción de inocencia, que implica que la carga de la prueba de los hechos constitutivos de la infracción recaiga sobre la Administración, con la prohibición absoluta de utilizar pruebas obtenidas con vulneración de derechos fundamentales y el derecho a la utilización de los medios de prueba adecuados para la defensa (por todas, SSTC 7/1998, de 13 de enero, 14/1999, de 22 de febrero, 81/2002, de 27 de marzo, y 9/2003, de 20 de enero).

El presente estudio va a prescindir del análisis en todos sus trámites del procedimiento administrativo sancionador regulado por el RD 1398/1993, de 4 de agosto, toda vez esa empresa excede con mucho de mi propósito al haber sido objeto de estudio exhaustivo y riguroso tanto por manuales de Derecho Administrativo como por monografías sobre la materia. Por el contrario, me propongo centrar este trabajo en la jurisprudencia acerca de las denominadas actuaciones previas fase que, en puridad, no constituye procedimiento administrativo sancionador propiamente dicho pues queda extramuros de él, pero que guarda con éste una íntima y estrecha imbricación. Por consiguiente, se va a analizar dicha fase y su incidencia sobre el procedimiento administrativo sancionador: en particular las garantías del administrado y su influencia sobre la prescripción de la infracción y la caducidad del procedimiento.

\section{NATURALEZA Y FINALIDAD DE LAS ACTUACIONES PREVIAS}

El art. 69.2 LPAC bajo la rúbrica “iniciación de oficio" dispone:

“Con anterioridad al acuerdo de iniciación, podrá el órgano competente abrir un período de información previa con el fin de conocer las circunstancias del caso concreto y la conveniencia o no de iniciar el procedimiento". 
Por su parte, el art. 12 del RD 1398/1993, de 4 de agosto establece²:

“1. Con anterioridad a la iniciación del procedimiento, se podrán realizar actuaciones previas con objeto de determinar con carácter preliminar si concurren circunstancias que justifiquen tal iniciación. En especial, estas actuaciones se orientarán a determinar, con la mayor precisión posible, los hechos susceptibles de motivar la incoación del procedimiento, la identificación de la persona o personas que pudieran resultar responsables y las circunstancias relevantes que concurran en unos y otros.

2. Las actuaciones previas serán realizadas por los órganos que tengan atribuidas funciones de investigación, averiguación e inspección en la materia y, en defecto de éstos, por la persona u órgano administrativo que se determine por el órgano competente para la iniciación o resolución del procedimiento".

\section{No forman parte del procedimiento}

Ya en la Sentencia de 24 de septiembre de 1976 (RAJ 4564) el TS declaró que:
"las investigaciones previas no forman parte del expediente sancionador, no son propiamente expediente administrativo, sino un antecedente que la ley faculta a la Administración para llevar a cabo y a la vista de su resultado acordar lo procedente; esto es, el archivo de las actuaciones o la orden de incoación del expediente".

La diferencia entre lo que hoy se llaman "actuaciones previas" (art. 69.2 Ley 30/1992) y antes "información reservada" (art. 134.2LPA de 1958), con el procedimiento sancionador propiamente dicho ha sido subrayada por el TS desde hace tiempo. Se trata, pues, de actuaciones que tienen lugar extramuros del procedimiento sancionador propiamente dicho, cuya finalidad no va más allá de una apreciación acerca de si, efectivamente, se han producido o no los hechos de que se tiene noticia, y, en su caso, personas que hayan intervenido en aquéllos así como las circunstancias concurrentes en la producción de aquéllos y la intervención de éstas en los mismos, para poder así, concluir, si hay motivos razonables para iniciar el procedimiento sancionador.

Esto mismo es lo que, con otras palabras, viene a decir el artículo 12.1 del RD 1398/1993, de 4 de agosto. Las Ilamadas "actuaciones previas" constituyen una actuación administrativa preliminar y de carácter contingente que trata de comprobar si "prima facie" puede considerarse que hay una base seria para abrir el procedimiento sancionador propiamente dicho. Su finalidad es dar a conocer las circunstancias del

2 El art. 134 LPA de 1958 en el seno del procedimiento administrativo sancionador disponía: “1. El procedimiento deberá incoarse por providencia del órgano competente en cada caso. 2. A tal efecto, al recibir comunicación o denuncia sobre una supuesta infracción administrativa, podrá acordar la instrucción de una información reservada antes de dictar la providencia en que se decida la incoación del expediente o, en su caso, el archivo de las actuaciones". 
caso, las personas presuntamente infractoras, así como la valoración de si concurren indicios racionales para estimar cometida una infracción, evitando la tramitación de un procedimiento inútil. Por consiguiente, "la apreciación de si hay o no prescripción no constituye materia propia de unas actuaciones previas porque su comprobación va más allá de una valoración de principio, exigiendo, además, una precisión en los datos que normalmente no se puede tener en ese momento"3.

Así pues, el art. 12 del RD 1398/1993, de 4 de agosto, define las actuaciones previas a la iniciación del procedimiento sancionador como aquellas realizadas por los órganos con atribuciones para la investigación, averiguación e inspección, dirigidas a determinar si concurren circunstancias que justifiquen tal iniciación, señalándose, en especial, las que tengan por objeto determinar, con la mayor precisión posible, los hechos susceptibles de motivar la incoación del procedimiento, la identificación de la persona o personas que pudieran resultar responsables y las circunstancias relevantes que concurran en unos y otros ${ }^{4}$. En tanto que el art. 78 LPAC define como actos de instrucción del procedimiento aquellos que resultan necesarios para la determinación, conocimiento y comprobación de los datos en virtud de los cuales deba pronunciarse la resolución del procedimiento. Cabalmente, la normativa procedimental diferencia, por consiguiente, entre ambos tipos de actos administrativos -actuaciones no procedimentales y actuaciones de instrucción del procedimiento- no en razón de su relación temporal con el acto administrativo que, de manera formal, declara abierto el procedimiento, sino por el objeto material de la actuación -determinación de distintos tipos de hechos- en relación con su distinta finalidad -motivar la incoación del procedimiento, en el primer caso, y resolver sobre el procedimiento, en el segundo caso.

3 STS 27 de febrero de 2001 (RAJ 1369).

4 Vid SAN 22 junio de 2005 (RJCA 2005/900) que rechaza la primera de las alegaciones de la actora en relación con la alegada invalidez de las diligencias previas. En efecto, "el inicio del procedimiento sancionador, del que forman parte las denominadas diligencias previas, es competencia exclusiva de la Administración, en este caso, haciendo uso de las potestades de supervisión e inspección que la legislación sobre el Mercado de Valores atribuye a la Comisión Nacional del Mercado de Valores que, con arreglo al artículo 85 de LMV puede recabar la información que estime oportuna sobre las materias de su competencia, pudiéndose realizar cuantas inspecciones y comprobaciones se consideren oportunas. $Y$ dentro de dichas potestades de supervisión se encuentran, con arreglo al artículo 12 del Real Decreto 1398/1993, las actuaciones realizadas con carácter previo al inicio propiamente dicho del procedimiento sancionador y, en definitiva, al objeto de determinar si concurren circunstancias que justifiquen la apertura del expediente sancionador para el caso de que existan indicios suficientes de la comisión de una falta o infracción administrativa estándole vedado a la Administración, con arreglo a una reiterada jurisprudencia del Tribunal Supremo, permanecer inactiva ante la denuncia de posibles infracciones sancionables. Y si, como ocurre en este caso, una mera denuncia, además formulada por un empleado despedido por la propia Agencia de Valores denunciada, no constituye motivo suficiente para la inmediata iniciación de un procedimiento sancionador, ni tan siquiera para la concreción de un determinado cargo, mal puede decirse que se ha eludido el procedimiento debido ni, menos aún si cabe, la incompetencia del órgano supervisor de la CNMV pues, como con toda claridad establece el art. 12 del RD citado, las actuaciones previas serán realizadas "por los órganos que tengan atribuidas funciones de investigación, averiguación e inspección en la materia”, de ahí que nada quepa oponer, en definitiva, a la actuación desarrollada por la CNMV en la averiguación de los hechos denunciados, mediante la realización de una visita de supervisión a la Agencia, haciendo uso de las potestades que legalmente tiene encomendadas". 
De conformidad con lo expuesto, cabe concluir que las actuaciones administrativas documentadas en el expediente con anterioridad al dictado del acuerdo de iniciación del expediente sancionador guardan relación directa con la determinación del hecho sancionable y, por consiguiente, han de calificarse como actuaciones previas a la iniciación de dicho procedimiento5.

\section{Clases: Actuaciones previas con conocimiento del interesado e información reservada}

Las actuaciones previas pueden ser llevadas a cabo de manera pública y con conocimiento del interesado, o bien de manera reservada.

En efecto, dentro de las actuaciones previas cabe la práctica de información reservada, es decir, la realizada sin conocimiento ni intervención del posible imputado que participa de la misma naturaleza que las actuaciones previas en las que se integra, pero que justifican su carácter meramente interno en la evitación de una publicidad que permita el conocimiento de la intervención administrativa por el afectado, en aras de garantizar la no frustración de los fines perseguidos por el procedimiento. Por ende, no se genera indefensión ni se vulnera el derecho de audiencia si se realizan las actuaciones previas sin intervención del sancionado, pues exigir dicha intervención contradice de plano la finalidad de la información previa reservada. Así pues, la intervención del interesado no es necesaria ni por ello se genera indefensión, puesto que aun no se ha concretado la imputación contra el mismo. Por ello, no disfruta el imputado del derecho de audiencia y contradicción en esta fase, debiendo ser garantizados tales derechos con posterioridad, en el seno del procedimiento sancionador, una vez notificado el acuerdo de incoación.

Por su parte, el TC también ha afirmado que las actuaciones previas no constituyen expediente administrativo sancionador. Sobre este asunto cabe destacar la sentencia $272 / 2006^{6}$, que con relación a la queja referida a la pretendida vulneración del

5 STSJ Comunitat Valenciana 21 de mayo de 2003 (RJCA 2004/196) a efectos de apreciar la denominada caducidad inicial en el que los actores alegan como motivo impugnatorio formal, la caducidad del expediente sancionador, por lo que la Administración dejó transcurrir el plazo de dos meses previsto en el art. 6.2 del RD 1398/1993, de 4 de agosto, sin que se les notificara el procedimiento. Dicha alegación no puede prosperar, puesto que ha de ser tomado como dies a quo para el cómputo del plazo de caducidad del expediente el 22 de abril de 1999, fecha en que el Ingeniero Jefe de la Demarcación de Costas en Valencia dictó Resolución acordando la incoación de expediente sancionador por la comisión de una supuesta infracción consistente en construcción de voladizos de un edificio en el Paseo de San Pedro, TM. de Altea, entre los hitos M-39 y M-40, invadiendo el dominio público marítimo terrestre. La emisión con anterioridad por el Servicio de Vigilancia de Costas de los informes que obran en el expediente constituye "actuaciones previas" encuadrables en el art. 12 del RD 1398/1993 encaminadas a averiguar con carácter preliminar la concurrencia de circunstancias que justificaran la iniciación del expediente administrativo.

6 La demanda de amparo se dirige contra la resolución del Ministro de Defensa de 14 de marzo de 2001 confirmada en reposición por Resolución de 10 de julio de 2001 que impuso al recurrente una sanción 
derecho de defensa (art. 24.2 CE) por incoarse el expediente mediante información reservada en la que no se le puso de manifiesto al recurrente la acusación ni se le informó de la procedencia de los documentos respecto de los que se le requería para que reconociese su autoría, afirma:

"la práctica de la información reservada previa al expediente disciplinario, prevista en el art. 32.2 de la LO 11/1991, de 17 de junio, del régimen disciplinario de la Guardia civil7, no ha ocasionado indefensión alguna al recurrente, a quien le fue puesta de manifiesto inmediatamente y tuvo oportunidad de negar ya entonces como así lo hizo su relación con los hechos investigados, sin que tampoco quepa apreciar vulneración del principio acusatorio por no haberse efectuado en la información reservada, que no tiene carácter sancionador (sino que mediante la misma se pretende la averiguación de unos hechos para, en su caso, incoar un expediente disciplinario), un acto de acusación formal, pues el momento procesal oportuno para ello es el pliego de cargos que se formula en el expediente disciplinario (por todas, SSTC 297/1993, de 18 de octubre, F. 4, y 205/2003, de 1 de diciembre, F. 5), sin perjuicio de que las diligencias practicadas en la información reservada puedan, en su caso, ser valoradas por el órgano decisor. Por lo demás, el examen de las actuaciones permite comprobar que el recurrente conoció oportunamente los cargos que contra él se formulaban, habiéndosele dado correcto traslado del pliego de cargos, así como de la propuesta de resolución, respecto de los cuales tuvo ocasión de defenderse en los términos que estimó pertinentes" (F.J Sexto).

En efecto, en el ATC 204/1993, de 28 de junio, el TC afirmó que "es cierto que las declaraciones prestadas por terceros en la fase de información reservada, previa a la incoación del procedimiento sancionador por parte de la autoridad competente, no revisten las garantías propias de la fase contradictoria del procedimiento, en donde las diligencias de comprobación son practicadas por el instructor con la participación de la persona sujeta al procedimiento (de acuerdo con los arts. 134 y 136 de la LPA de 1958 , en la actualidad sustituidos por los arts. 69, 137, 135, 80 y 81 de la Ley del Procedimiento Administrativo Común 30/1992)" ( F.J. 3).

de un año de suspensión de empleo por la comisión de una falta disciplinaria muy grave del art. 9.9 de la LO 11/1991, de 17 de junio, del Régimen disciplinario de la Guardia civil, por las manifestaciones efectuadas sobre aspectos internos de la Guardia civil que aparecieron publicadas en diversos diarios, así como contra la Sentencia de la Sala de lo Militar del TS de 31 de marzo de 2003, que desestima el recurso contenciosodisciplinario militar interpuesto contra la referida resolución sancionadora. El recurrente denuncia que las resoluciones administrativa y judicial impugnadas en amparo han vulnerado sus derechos a la presunción de inocencia, a la defensa, y a un proceso con todas las garantías, así como sus derechos al honor y a la intimidad personal, su derecho a la libertad de expresión (en conexión con el derecho de asociación y la libertad sindical) y el principio de legalidad en materia sancionadora.

$7 \quad$ El art. 32.2 de la LO 11/1991, de 17 de junio, preceptuaba que: "2. Antes de acordar la incoación de un procedimiento, la autoridad competente podrá acordar la práctica de una información reservada para el esclarecimiento de los hechos". Por su parte, en parecidos términos la vigente LO 12/2007, de 22 de octubre, de Régimen Disciplinario de la Guardia Civil en el art. 39.5 dispone: "Con anterioridad al acuerdo de inicio, la Autoridad disciplinaria podrá ordenar la práctica de una información reservada para el esclarecimiento de los hechos, la determinación de sus presuntos responsables y la procedencia de iniciar o no el procedimiento sancionador". 
Y en la posterior sentencia 56/1998, de 16 de marzo $^{8}$, en el F.J. 5 proclama:

"La primera de las diligencias cuya valoración se impugna a radice es la denominada "información reservada" que precedió a la apertura del expediente disciplinario y que después se incorporó a él. Dicha información, prevista genéricamente en el art. 28 del Reglamento de Régimen Disciplinario de los Funcionarios de la Administración del Estado.

Con independencia de que la peculiar característica que domina y da nombre a esta diligencia (su carácter inicialmente "reservado") deba ser tenida en cuenta por el órgano decisor a la hora de valorar su contenido, debe señalarse que de las condiciones en las que se practicó no se infiere la necesidad de proscribir su valoración para salvaguardar el equilibrio esencial del procedimiento y para impedir un posible efecto material de indefensión (ATC 204/1993). Adviértase que, por una parte, dicho informe fue encargado conforme a Derecho por el Ministerio de Justicia a un funcionario concreto en el ejercicio regular de su función y en que dicho funcionario describió pormenorizadamente su actividad para realizarlo y los fundamentos fácticos de sus conclusiones. Obsérvese también que su escrito se incorporó al expediente una vez incoado éste y que, de nuevo con independencia de las oportunidades de defensa que el hoy recurrente tuviera en la fase judicial, ello le dio oportunidad de rebatir su contenido en las dos ocasiones en las que se le concedió audiencia y de solicitar un nuevo testimonio de su autor o, en general, las diligencias que estimara convenientes para sustentar su contradicción.

Corrobora las afirmaciones anteriores nuestra jurisprudencia relativa a que las diligencias y actas de la Inspección de los Tributos constituyen un primer medio de prueba sobre los hechos que reflejan y que su "valor o eficacia ha de medirse a la luz del principio de la libre valoración de la prueba. A ello debe añadirse que ese valor probatorio sólo puede referirse a los hechos comprobados directamente por el funcionario, quedando fuera de su alcance las calificaciones jurídicas, los juicios de valor o las simples opiniones que los inspectores consignen en las actas y diligencias"9.

\section{Carácter facultativo o potestativo}

En otro orden de consideraciones, ante la invocación de defectos formales entre otros por falta de actuaciones previas a la incoación del procedimiento sancio-

8 Cuando el recurrente ejercía sus funciones como Abogado del Estado fue expedientado y sancionado en vía administrativa (traslado con cambio de residencia) por infracción de la normativa sobre incompatibilidades a la que como tal funcionario estaba sometido, así como del deber de sigilo que comportaba su cargo. Tras acudir a la jurisdicción contencioso-administrativa, infructuosamente para sus intereses, en sede de amparo considera que su sanción y la confirmación judicial de la misma son la consecuencia de la vulneración de varios de sus derechos fundamentales: de un lado, el relato de hechos probados habría sido el fruto de una actividad probatoria falta de las imprescindibles garantías; de otro, la subsunción del mismo en los tipos de infracción aplicados carecería de la necesaria racionalidad.

9 Se citan en la sentencia la STC 76/1990, fundamento jurídico 8. ; ATC 974/1986 ; en relación con las actas de la Inspección de Trabajo, ATC 7/1984; en general, STC 169/1994. 
nador, la jurisprudencia ha reiterado que la práctica de instrucción o información reservada previa a la incoación del procedimiento sancionador, sólo se prevé con carácter facultativo ${ }^{10}$.

\section{LAS GARANTÍAS APLICABLES A “LAS ACTUACIONES PREVIAS”}

Estrechamente vinculado a la naturaleza de las actuaciones previas, surge inmediatamente la cuestión de las garantías aplicables a esta fase preliminar que no forma parte del expediente sancionador, así como la incidencia de las actuaciones de investigación y averiguación llevadas a cabo durante dicha fase previa en el procedimiento sancionador mismo. Ya se ha adelantado que por su carácter extra procedimiento sancionador y la existencia de actuaciones previas reservas no son predicables las garantías propias del presunto responsable en el procedimiento administrativo sancionador.

Sin embargo, según doctrina del TC las actuaciones previas no constituyen el procedimiento administrativo sancionador, lo cual no es óbice para predicar determinadas garantías constitucionales a esta fase que precede al expediente sancionador.

\section{La doctrina del TC}

\subsection{El derecho a no declarar contra sí mismo y a no confesarse culpable como garantías instrumentales del genérico derecho de defensa}

Acerca de las garantías aplicables en la fase preliminar de las actuaciones previas destaca la reciente sentencia 142/2009, de 15 de junio, dictada por el TC en recurso de amparo que se dirige contra la Sentencia del Juzgado de lo Contencioso-Administrativo núm. 2 de Sevilla, de 24 de enero de 2006, que desestima el recurso contenciosoadministrativo contra la Resolución de 16 de marzo de 2005, por la que se impuso a los recurrentes la sanción de pérdida de dos días de remuneración y suspensión de funciones durante igual período, por la comisión de una falta de atentado leve a la dignidad de los funcionarios o de la Administración.

Los recurrentes en amparo sostienen en primer lugar, que la sanción administrativa impuesta lo fue como consecuencia del mero ejercicio del derecho fundamental a no declarar contra sí mismos y a no confesarse culpables (art. 24.2CE), por lo que se habría vulnerado este derecho fundamental.

A tal efecto, el TC recuerda que la Constitución reconoce el derecho a no ser obligado a declarar en el art. $17 \cdot 3$, en relación con la persona detenida y en lo que

10 Vid a modo de ejemplo STSJ de Andalucía (Sala de Granada) 18 de marzo de 1996 (RJCA 1996/533). 
concierne al caso en el art. 24.2, con especial referencia, por tanto, al proceso penal, los derechos a no declarar contra sí mismo y a no confesarse culpable, derechos estrechamente relacionados con los de defensa y a la presunción de inocencia, de los que constituyen una manifestación concreta (SSTC197/1995, de 21 de diciembre, F. 6; 161/1997, de 2 de octubre, F. 5;127/2000, de 16 de mayo, F. 4; 67/2001, de 17 de marzo, F. 6; 18/2005, de 1 de febrero, F. 2; 76/2007, de 16 de abril, F. 8).

En cuanto al origen y contenido de ambos derechos, hemos explicado que frente al viejo proceso penal inquisitivo (regido por el sistema de prueba tasada en el que el imputado era considerado como objeto del proceso penal, buscándose con su declaración, incluso mediante el empleo de la tortura, la confesión de los cargos que se le imputaban), en el proceso penal acusatorio el imputado ya no es objeto del proceso, sino sujeto del mismo y, en cuanto tal, "ha de reconocérsele la necesaria libertad en las declaraciones que ofrezca y emita, tanto en lo relativo a su decisión de proporcionar la misma declaración, como en lo referido al contenido de sus manifestaciones. Así pues, los derechos a no declarar contra sí mismo y a no confesarse culpable son garantías o derechos instrumentales del genérico derecho de defensa, al que prestan cobertura en su manifestación pasiva, esto es, la que se ejerce precisamente con la inactividad del sujeto sobre el que recae o puede recaer una imputación, quien, en consecuencia, puede optar por defenderse en el proceso en la forma que estime más conveniente para sus intereses, sin que en ningún caso pueda ser forzado o inducido, bajo constricción o compulsión alguna, a declarar contra sí mismo o a confesarse culpable" SSTC197/1995, de 21 de diciembre, F. 6; 161/1997, de 2 de octubre, F. 5; 67/2001, de 17 de marzo, F. 7;; 18/2005, de 1 de febrero, F. 2; 76/2007, de 16 de abril, F. 8).

Por otra parte, los derechos alegados entroncan también con una de las manifestaciones del derecho a la presunción de inocencia, en virtud de la cual la carga de la prueba en el proceso penal corresponde a la acusación, sin que pueda hacerse recaer en el acusado la obligación de aportar elementos de prueba que supongan una autoincriminación (SSTC 161/1997, de 2 de octubre, F. 5; 18/2005, de 1 de febrero, F. 2; 76/2007, de 16 de abril, F. 8). O, en palabras del Tribunal Europeo de Derechos Humanos, el derecho a no autoincriminarse "presupone que las autoridades logren probar su caso sin recurrir a pruebas obtenidas mediante métodos coercitivos o de presión en contra de la voluntad de la persona acusada" (...).

Pero, con una u otra perspectiva, puede afirmarse que el contenido esencial de tales derechos es "la interdicción de la compulsión del testimonio contra uno mismo" y el reconocimiento de la necesaria libertad para declarar o no y para hacerlo en el sentido que se estime más conveniente" (STC 142/2009, F.J Tercero).

Este Tribunal ha establecido que el ejercicio de las potestades sancionadoras de la Administración le son de aplicación las garantías procedimentales previstas en el art. 24.2 CE, si bien no mediante su aplicación literal, sino en la medida necesaria para 
preservar los valores esenciales que se encuentran en la base de dicho precepto y la seguridad jurídica que garantiza el art. 9.3 CE ${ }^{11}$.

En concreto, hemos reconocido que el derecho a no declarar contra sí mismo, en cuanto garantía instrumental del derecho de defensa, rige y ha de ser respetado, en principio, en la imposición de cualesquiera sanciones administrativas, sin perjuicio de las modulaciones que pudiera experimentar en razón de las diferencias existentes ente el orden penal y el administrativo sancionador, precisando que "los valores esenciales que se encuentran en la base del art. 24.2 CE no quedarían salvaguardados si se admitiera que la Administración pudiera compeler u obligar al administrado a confesar la comisión o autoría de los hechos antijurídicos que se le imputan o pudieran imputar o a declarar en tal sentido" ${ }^{12}$ (STC 142/2009 F.J. Cuarto).

Con estos presupuestos entra el TC a examinar las particulares circunstancias concurrentes en el caso. Los recurrentes eran policías locales del Ayuntamiento de Sevilla y fueron sancionados por las manifestaciones vertidas en el seno de una información reservada, incoada a raíz de la denuncia de un ciudadano contra los agentes, al objeto de esclarecer los hechos denunciados y determinar en su caso las posibles responsabilidades administrativas que pudieran derivarse para los funcionarios implicados en los mismos. En concreto, tras negar los hechos que denunciaba el ciudadano y preguntados si tenían algo más que añadir, afirmaron que iban a aportar los recursos interpuestos por el ciudadano, para que se viera que en los mismos se hace un relato de hechos totalmente distinto al de la denuncia, lo que se demostró falso. Tal afirmación, fue calificada como "falsedad gratuita" y constitutiva de "un claro atentado a la dignidad del funcionario" por el Instructor del expediente de información reservada, es la que da lugar a la incoación del expediente disciplinario y al dictado de la resolución sancionadora, que afirma que los funcionarios "faltaron a la verdad de forma innecesaria para esclarecer los hechos que se dirimían y sin solicitud en tal sentido de la Instrucción del expediente de información reservada (...) lo que supone una falta de consideración para con el administrado y un atentado contra la gravedad y decoro que debe presidir la actuación de quienes están revestidos de la singular autoridad que da la pertenencia al cuerpo de la Policía Local”.

Del examen de las actuaciones se desprende que en ningún momento del procedimiento los recurrentes fueron forzados a realizar una declaración autoincriminatoria, lo que para el TC resultaría constitucionalmente inadmisible no sólo en el procedimiento administrativo sancionador propiamente dicho, sino también en la práctica de una información reservada pese a que ésta no tenga carácter sancionador; cuyas diligencias pueden ser valoradas por el órgano decisor en el procedimiento adminis-

11 SSTC 44/1983 de 24 de mayo, F. 3; 28/1989, de 6 de febrero, F. 6; 3/1999, de 25 de enero, F. 4; 117/2002, de 20 de mayo, F. 5; 205/2003, de 1 de diciembre, F. 3; 35/2006, de 13 de febrero, F. 3; 272/2006, de 25 de septiembre, F. 2; 70/2008, de 23 de junio, F. 4; 82/2009, de 23 de marzo, F. 3).

12 SSTC 197/1995, de 21 de diciembre; 272/2006, de 25 de septiembre; 70/2008, de 23 de junio; $32 / 2009$, de 9 de febrero. 
trativo sancionador propiamente dicho $^{13} \mathrm{y}$, en el presente caso, fueron las que sirven de fundamento a la sanción administrativa posteriormente impuesta. Por el contrario, consta acreditado que en la comparecencia en el expediente de información reservada los recurrentes fueron preguntados sobre los hechos denunciados, tras darse lectura al escrito de denuncia, realizando libremente y sin coacción alguna las declaraciones que tuvieron por conveniente y añadiendo, también de forma absolutamente voluntaria como destaca el órgano judicial las manifestaciones por las que posteriormente fueron sancionados (F.J. Quinto).

\subsection{Modulación derivada de la relación de sujeción especial}

Así pues el TC extiende la garantía de no autoincriminación propia del procedimiento sancionador a la fase previa o de información reservada, más a continuación establece una modulación de dicha garantía, fundada en la condición de policías locales de los demandantes de amparo, es decir, en la situación de sujeción especial de la que derivan deberes especiales para con la Administración y con los administrados, ligados a la autoridad de la que están investidos. El TC en F.J Sexto declara:

"es cierto que este Tribunal ha afirmado que el imputado en un proceso penal no
está sometido a la obligación jurídica de decir la verdad, sino que puede callar total
o parcialmente o incluso mentir, en virtud de los derechos a no declarar contra sí
mismo y a no confesarse culpable y que no pueden extraerse consecuencias nega-
tivas para el acusado derivadas exclusivamente del ejercicio de su derecho a guar-
dar silencio o de los derechos a no declarar contra sí mismo o a no confesarse cul-
pable (por todas, STC $76 / 2007$, de 16 de abril, F.J 8).

Ahora bien, de todo lo anterior no puede concluirse que los derechos a no declarar contra sí mismos y no declararse culpables en su conexión con el derecho de defensa consagren un derecho fundamental a mentir, ni que se trate de derechos fundamentales absolutos o cuasi absolutos, que garanticen la total impunidad cualesquiera que sean las manifestaciones vertidas en un proceso, o la ausencia absoluta de consecuencias derivadas de la elección de una determinada estrategia defensiva. Ello no es así ni siquiera en el proceso penal. Pues aunque hemos afirmado que la futilidad del relato alternativo no puede sustituir la ausencia de prueba de cargo, so pena de asumir el riesgo de invertir la carga de la prueba, también hemos declarado que, en cambio, la versión de descargo puede servir como contraindicio o como elemento de corroboración de los indicios a partir de los cuales se infiere la culpabilidad $^{14}$. Nuestra doctrina, por tanto, desvirtúa el argumento expuesto en la demanda según el cual ninguna consecuencia negativa puede derivarse de la falsedad de las afirmaciones de los recurrentes por haber sido emitidas en el ejercicio de su derecho a no confesarse culpables.

13 SSTC 56/1998, de 16 de marzo, F.J. 5; 276/2006, de 25 de septiembre, F.J. 6; ATC 204/1993, de 28 de junio, F.J. 3.

14 SSTC 220/1998, de 16 de noviembre, F.J 6; 155/2002, de 22 de julio, F.J 15; 135/2003, de 30 de junio, F.J 3; 147/2004, de 13 de septiembre, F.J 6; 55/2005, de 14 de marzo, F.J 5, y 10/2007, de 15 de enero, F.J 5). 
La ponderación del conjunto de las circunstancias concurrentes exige la valoración de dos datos esenciales. En primer lugar, en el presente caso no nos encontramos ante el imputado en un proceso penal, sino ante una comparecencia en una información reservada, lo que impide la traslación mecánica y acrítica de las garantías y conceptos propios del orden penal, pues la amplitud de las garantías del art. $24 \mathrm{CE}$ en uno y otro contexto no puede ser la misma. Además, es de señalar el carácter de agentes de la policía local de los recurrentes, que comparecen en el expediente de información reservada en su calidad de tales para prestar su versión de los hechos tras la denuncia de un ciudadano a raíz de una actuación en el ejercicio de sus funciones, que había concluido con la imposición de dos multas al ciudadano en cuestión. En las circunstancias concretas del presente caso, no puede obviarse que, en cuanto miembros de las fuerzas y cuerpos de seguridad de conformidad con la previsto en el art. 2 de la LO 2/1986, de 13 de marzo se encuentran en una posición jurídica que difiere de la del resto de los ciudadanos, de la que derivan deberes especiales para con la Administración y con los administrados, ligados a la autoridad de la que están investidos y, en lo que atañe al caso que nos ocupa, una mayor exigibilidad de rigor en las manifestaciones vertidas en el ejercicio de sus cargos, incluso cuando como sucede en una información reservada se investigan hechos de los que pueden derivarse responsabilidades administrativas".

Según el Alto Tribunal la existencia de dicha relación administrativa especial no priva a los afectados de sus derechos fundamentales, y en concreto de su derecho a no declarar contra sí mismos y de su derecho de defensa, pero sí puede modular el ejercicio de los mismos, permitiendo limitaciones que son constitucionalmente admisibles en la medida en que resulten estrictamente indispensables para el cumplimiento de la misión o función derivada de aquella situación especial'15. Según el TC la Constitución permite, entre otras, la modulación del derecho a la legalidad sancionadora consagrado en el art. 25.1 CE ${ }^{16}$ o del derecho a la libertad de expresión consagrado en el art. 20.1 a) CE (por todas, STC 272/2006, de 25 de septiembre, F. 9 y las allí citadas) cuando de miembros de las fuerzas armadas y de las fuerzas y cuerpos de seguridad se trata. $Y$, en esa misma línea, debemos afirmar ahora que también los derechos fundamentales invocados por los recurrentes encuentran limitaciones derivadas de su condición de policías locales y que las mismas determinan que quede fuera del ámbito de cobertura de los derechos fundamentales a no declarar contra sí mismos y a la defensa (art. 24.2 CE) la realización de unas manifestaciones en un expediente de

15 Por todas, SSTC 21/981, de 15 de junio, F. 15; 31/2000, de 3 de febrero, F. 4; 74/2004, de 22 de abril, F. 6;179/2004, de 21 de octubre, F. 6, citadas por STC 142/2009.

16 El TC en la sentencia 81/2009, de 23 de marzo, (F.J 5) afirma que procede recordar que "las llamadas relaciones de sujeción especial no son entre nosotros un ámbito en el que los sujetos queden despojados de sus derechos fundamentales o en el que la Administración pueda dictar normas sin habilitación legal previa. Estas relaciones no se dan al margen del Derecho, sino dentro de él y por lo tanto también dentro de ellas tienen vigencia los derechos fundamentales y tampoco respecto de ellas goza la Administración de un poder normativo carente de habilitación legal, aunque ésta pueda otorgarse en términos que no serían aceptables sin el supuesto de esa especial relación (... entre otras, SSTC 2/1987, 42/1987, 69/1989, 61/1990, 234/1991, de 10 de diciembre; 26/2005, de 14 de febrero; 229/2007, de 5 de noviembre ; y 162/2008, de 15 de diciembre; 132/2001, de 8 de junio; 50/2003, de 17 de marzo; 26/2005, de 14 de febrero). 
información reservada que no sólo se demostraron abiertamente falsas, sino que implican la imputación al ciudadano al que previamente habían sancionado, y con motivo del esclarecimiento de la denuncia presentada por éste a raíz de su actuación profesional, de la presentación de una denuncia falsa contra los agentes, con las eventuales consecuencias que ello podría tener para aquél, como destaca el órgano judicial. Tal modo de actuar resulta incompatible con el cumplimiento de la función que los agentes tenían asignada, pues perturba el normal funcionamiento de la Administración y quiebra las expectativas de seguridad y confianza en la actuación de los agentes de la policía por parte de los ciudadanos y de los poderes públicos.

A la luz de todo lo expuesto, concluye el TC que la conducta por la que los recurrentes fueron sancionados no constituye un acto de ejercicio legítimo del derecho fundamental a no declarar contra sí mismos y a no confesarse culpables (art. 24.2 CE), en relación con el derecho de defensa, sino una clara extralimitación de tal ejercicio, teniendo en cuenta las modulaciones impuestas al mismo en función de los especiales deberes que los recurrentes tenían ante la Administración y ante los ciudadanos, en su condición de policías locales. En definitiva, para el TC es de aplicación la garantía de no declarar contra sí mismos y a no confesarse culpable en la fase preliminar de las actuaciones previas, pero modulada por la relación de sujeción especial con la Administración en virtud de su condición de policías locales.

Otro, en cambio ha sido el voto particular que formula el Magistrado D. Jorge Rodríguez-Zapata Pérez. Pues según el magistrado disidente la resolución del recurso de amparo debió partir del dato esencial de que las manifestaciones inveraces de los agentes policiales, cuya sanción se recurre, no se efectuaron en el ámbito de un proceso penal ni de un procedimiento administrativo sancionador, sino en el curso de una "información reservada”. Constituye una actuación potestativa de la Administración que tiene como finalidad verificar si concurren circunstancias que justifiquen la iniciación de un expediente disciplinario. No tienen carácter sancionador, sino que mediante las mismas se pretende la averiguación de unos hechos para, en su caso, incoar un expediente disciplinario. Resulta improcedente, por ello, la invocación por los recurrentes de los derechos a no declarar contra sí mismos y a no confesarse culpables (art. 24.2CE) puesto que estos derechos se proyectan, exclusivamente, sobre el proceso penal y los procedimientos administrativos sancionadores. Ésta debió ser, según el magistrado, la razón de decidir de la Sentencia, máxime cuando no consta, ni se ha alegado, un uso desviado por la Administración de la facultad de iniciar la información preliminar.

\section{La doctrina de los Tribunales ordinarios}

\subsection{No resultan aplicables las garantías propias del procedimiento administrativo sancionador}

Es doctrina del TS que las actuaciones previas al no formar parte del procedimiento sancionador, no pueden predicarse las garantías propias de éste a aquél. En 
particular, sobre el derecho del administrado a conocer de estas actuaciones previas y la posible vulneración de su derecho fundamental a no declarar contra sí mismo cuando se colabora con la Administración en la práctica de las mismas, cuando más tarde por dichas declaraciones se incoa el procedimiento sancionador, el TS entiende que el derecho a conocer de la acusación sólo surge cuando el expediente lo permite por haber llegado a un momento en que las imputaciones puedan ya formularse como fundamento sólido. A este respecto, concluye la STS 27 de febrero de 2003 (RAJ 2518) que no se vulnera el derecho a no declarar contra sí mismo por el hecho de que el infractor haga declaraciones autoinculpatorias en la fase de investigaciones previas antes de que la Administración formule imputación contra él, por no saberse aún contra quien se ha de dirigir el expediente. En otro caso, si las actuaciones previas se dilataran precisamente para lograr, antes de la formulación del pliego de cargos, que quien ignora su condición de acusado administrativo preste una declaración que no prestaría de conocer dicha circunstancia, podría resultar eventualmente afectado el derecho que todos tienen a no declarar contra sí mismos.

\subsection{Los controles técnicos previos se asimilan a las actuaciones previas}

Se asimilan a las diligencias previas los controles técnicos previos. En este sentido la STS 20 de abril de 2006 (RAJ 2155) recurso de casación de Price Waterhouse Auditores, SA relativo a la vulneración de diversas garantías esenciales del procedimiento sancionador, en lo que aquí importa la integración del control técnico en el procedimiento sancionador con vulneración de las garantías propias del procedimiento, y la ausencia de separación entre las fases de instrucción y resolución.

En cuanto a la primera alegación, la Sentencia impugnada había afirmado que: el art. 53 del RD 1636/90, prevé la posibilidad de realizar actuaciones previas de información reservada, con anterioridad a la incoación del procedimiento sancionador, y el art. 12 RD 1398/93, establece, con carácter general, la posibilidad de realización de tales actuaciones previas con objeto de determinar si concurren circunstancias que justifiquen la iniciación de procedimiento sancionador. Se trata, en definitiva, de actuaciones realizadas con anterioridad a la iniciación del procedimiento, lo que determina que no pueda hablarse en la práctica de las mismas de interesados ni del ejercicio de los derechos que les correspondería en el procedimiento sancionador y dentro de tales actuaciones previas, han de encuadrarse las actuaciones de control previo.

Para el TS la fase de control técnico es una actividad inspectora que constituye un presupuesto del procedimiento sancionador, en el sentido de que sólo si a resultas de dicha actuación existen indicios de infracción, el órgano competente acordará la incoación del correspondiente procedimiento sancionador. Por consiguiente, sea cual sea el peso que luego se le otorgue en el procedimiento sancionador a la previa activi-

208 dad de inspección, en modo alguno podrá aducirse infracción alguna de las garantías 
del procedimiento sancionador en relación con dicha fase, que es previa al procedimiento sancionador propiamente tal. Será a lo largo de éste cuando el afectado podrá solicitar la práctica de diligencias probatorias que considere precisas y podrá formular cuantas alegaciones entienda procedentes al objeto de tratar de desvirtuar las conclusiones a las que la actividad inspectora hubiera podido llegar, si es que los cargos imputados se basan en ellas. Pero ni por ello se integra la fase inspectora en el procedimiento sancionador stricto sensu ni la misma supone, por consiguiente, merma alguna de las garantías de las que el expedientado disfruta a lo largo del mismo.

En la realización del control técnico se limita a realizar las averiguaciones necesarias para determinar si resulta procedente o no la incoación misma del procedimiento, por lo que no se realiza ningún acto que suponga la emisión de un prejuicio sobre la culpabilidad o no de la entidad controlada. De ahí que no le resulte aplicable el principio constitucional que exige la separación entre las fases de instrucción y resolución ${ }^{17}$.

\subsection{Incidencia de informes y averiguaciones efectuados durante el trámite de actuaciones previas en el posterior procedimiento sancionador}

Esta cuestión ha sido objeto de variada consideración por los Tribunales. Se trata de casos en los que se alega la nulidad del expediente sancionador por no haber incorporado al mismo el Instructor los elementos inculpatorios contenidos en el expediente informativo previo instruido utilizados por la Administración no sólo para acordar la iniciación de procedimiento sancionador, sino como fundamento de la propia tipificación de los hechos e imposición de la sanción, y todo ello sin haber incorporado tales actuaciones previas al expediente sancionador y sin dar traslado de las mismas al inculpado.

Este es el supuesto enjuiciado en la STSJ Comunitat Valenciana (RJCA 2007/911). La Dirección General de Industria y Energía incoó, a efectos informativos, el expe-

17 En el mismo sentido STS 15 de noviembre de 2004 (RAJ 2005 /856). Para el TS resulta procedente poner de manifiesto, la neta distinción que existe entre la fase de control técnico, que tiene un carácter previo a la decisión de incoación del expediente sancionador y que por lo tanto puede asimilarse a la que en el procedimiento administrativo común se denomina "actuaciones previas" (art. 12 RD 1398/1993), y las fases propias del procedimiento, como son la incoación, tramitación y resolución. En la realización del control técnico se limita a realizar las averiguaciones necesarias para determinar si resulta procedente o no la incoación misma del procedimiento, por lo que no realiza ningún acto que suponga la emisión de un prejuicio sobre la culpabilidad o no de la entidad controlada. Una vez iniciado el procedimiento su intervención sólo aparece en la fase de resolución, por lo que se ha respetado el principio constitucional que exige la separación entre las fases de instrucción y resolución. Sobre este extremo es relevante la cita de la doctrina del TEDH, y más concretamente la Sentencia 22-4-1994, asunto Saraiva de Carvalho contra Portugal, en la que se admite la actuación de un mismo Juez en un mismo proceso en fases o actuaciones diferentes y concluye que sólo en el supuesto de que se hayan realizado actos de instrucción o acusación y de resolución existe violación del derecho invocado, lo que no ocurre en el presente caso. 
diente con la finalidad de determinar con carácter preliminar si concurrían circunstancias que justificasen la iniciación de expediente sancionador por el incidente en el suministro de energía eléctrica con origen en la Subestación de La Plana (Castellón) y cuyas consecuencias habían afectado a una parte significativa de los consumidores de la Provincia de Castellón. Seguidamente, el Director General de Industria y Energía dictó resolución acordando la iniciación de expediente sancionador para determinar las responsabilidades en que hubiera podido incurrir Iberdrola, como titular de las instalaciones eléctricas, por la presunta comisión de una infracción administrativa derivada de la Ley 54/1997, de 27 de noviembre, del Sector Eléctrico. Tras la formulación de alegaciones por Iberdrola, el Instructor del expediente dictó propuesta de resolución, en cuya fundamentación jurídica se atribuía especial importancia, a efectos de la imputación a Iberdrola de la perpetración de los hechos al informe efectuado por Red Eléctrica de España obrante en las actuaciones previas, informe que no figuraba unido al expediente sancionador, y del que la inculpada sólo tuvo conocimiento una vez se le dio traslado de dicha propuesta de resolución, y tras solicitar al Instructor que le remitiera copia del mismo para poder cumplimentar adecuadamente el trámite de alegaciones.

A tenor de todo lo anterior, estima la Sala que ese informe elaborado por Red Eléctrica de España fue utilizado por la Administración no sólo para acordar la iniciación de procedimiento sancionador, sino como fundamento de la propia tipificación de los hechos consistentes "en no aplicar los criterios de explotación que garantizasen la seguridad de las instalaciones, prestando el servicio de forma regular y continua", de manera que si bien tal informe, en su condición de actuación previa, no tenía que formar parte del expediente sancionador propiamente dicho, sino que constituía un mero antecedente del mismo, sin embargo, para ser tenido como elemento de prueba inculpatorio de los hechos infractores en el seno de dicho expediente sancionador debió haber sido incorporado a éste por la Administración una vez incoado, quedando a disposición de la inculpada para que, con conocimiento de su contenido, pudiera haber propuesto los medios de prueba que a su derecho hubiera estimado convenientes y establecer la estrategia defensiva propia e imprescindible en todo proceso acusatorio. Por lo que estima que el órgano sancionador dictó la resolución sancionadora sin respetar el sistema de garantías establecido en las normas rectoras del procedimiento, cuyo designio final es la defensa del administrado frente a la Administración, y por consiguiente, el acto administrativo resulta viciado. En consecuencia, la resolución sancionadora, en cuanto imputa a la actora la perpetración del referido hecho infractor, es contraria a Derecho (F.J. Cuarto).

\section{INCIDENCIA DE LAS ACTUACIONES PREVIAS SOBRE LA PRESCRIPCIÓN DE LA INFRACCIÓN Y SOBRE LA CADUCIDAD DEL EXPEDIENTE SANCIONADOR}

Es necesario partir de la distinción entre prescripción de la infracción y caducidad

210 del procedimiento. Conviene precisar que, conceptualmente, la prescripción es un 
instituto que se refiere a la infracción y consecuente extinción de la responsabilidad de este orden y terminación también del impulso de oficio o actividad de la Administración dirigida a perseguir aquella falta, mientras que la caducidad se refiere al procedimiento; que la prescripción se interrumpe con la iniciación del expediente administrativo; y que la paralización del procedimiento, por el tiempo exigido produce la denominada caducidad del procedimiento ${ }^{18}$.

El fundamento de la prescripción y de la caducidad, tan discutido, se liga, como señaló esta Sala en Sentencia de 7 de diciembre de 1987 (RAJ 9371), al principio de la seguridad jurídica.

Asimismo, tanto la prescripción como la caducidad son excepciones que puede oponer el sancionado en su defensa, de suerte que restringir de algún modo, no expresamente autorizado, el ejercicio de la misma, sólo podría dar lugar, por el contrario, a su total indefensión ${ }^{19}$.

\section{Actuaciones previas y prescripción de la infracción}

La propia naturaleza de la prescripción, tal y como declara el TS en Sentencia de 13 de junio 1989 (RAJ 4382), supone "una condición objetiva para que se ejerza el poder sancionador de la Administración, de ahí que deba ser apreciada de oficio por la propia Administración, y por supuesto por el Tribunal de lo ContenciosoAdministrativo".

Es oportuno recordar, como lo hace la STSJ Extremadura de 10 de septiembre de 1997 (RJCA 1875) que la institución de la prescripción, hasta la Ley 30/1992, de 26 noviembre, adolecía en nuestro Derecho Administrativo Sancionador de un vacío normativo con carácter general. De otra parte ha sido unánime la jurisprudencia al admitirla institución de la prescripción en el ámbito del Derecho administrativo sancionador, al estimar que sería una incongruencia su vigencia en el ámbito del Derecho penal, en base al principio de seguridad jurídica, y no rigiese en el ámbito de las infracciones administrativas, cuyo contenido del injusto debe tener menos entidad (SSTS 14 abril y 14 junio 1989 (RAJ 2852 y 4386). Esa equiparación con el derecho punitivo llevó a la jurisprudencia a la aplicación analógica del CP, admitiéndose la vigencia tanto en cuanto al cómputo del tiempo como a su interrupción; interrupción que además aparece como una exigencia inherente a la propia institución y que se produce por la mera iniciación del procedimiento (STS 22 enero 1991), volviendo a correr cuando el mismo quede paralizado, con independencia de la trascendencia de esa inactividad a los meros efectos del procedimiento y que daría lugar en su caso, a la caducidad del mismo, institución bien diferente).

18 Entre otras, STS 26 de mayo de 1986 (RAJ 3334), STS de 15 julio 1988 (RAJ 4386) y STSJ Cataluña de 22 de mayo de 1995 (RJCA 398).

19 SSTS de 31 de diciembre de 1990 (RAJ 10430) y de 30 de junio de 1990 (RAJ 5759). 
Respecto del plazo de prescripción de la infracción es obligado diferenciar dos periodos, antes de la entrada en vigor de la Ley 30/1992 y tras la entrada en vigor de la misma. En este sentido, la STS 2 de marzo de 2005 (RAJ 1866) ${ }^{20}$ pone de manifiesto las diferencias entre la LPA de 1958 y la LPAC. Así durante la vigencia de la LPA interrumpe el plazo de prescripción de la infracción el inicio por la Administración de actuaciones de averiguación, lo que comprende las actuaciones previas, no sujeto pues a la notificación del acuerdo de incoación. Por el contrario, en la LPAC sólo interrumpe el plazo de prescripción el inicio con conocimiento del interesado del acuerdo de iniciación, es decir, su notificación.

Como es bien sabido, esta Ley supuso un cambio esencial en la cuestión ahora debatida, puesto que reguló el procedimiento sancionador con una perspectiva garantista plenamente adaptada a las exigencias y principios constitucionales y, en consecuencia, de forma claramente diferente a la vieja LPA de 1958, sumamente escueta en su regulación. Ahora bien, junto con el incremento en las previsiones tendentes a asegurar los principios de presunción de inocencia y de defensa, también estableció expresamente plazos de prescripción generales -a reserva de regulaciones específicas- tanto para las infracciones como para las sanciones, cosa que no hacía la Ley de Procedimiento Administrativo.

En este sentido, frente a lo establecido por la Ley 30/1992, que exige para interrumpir la prescripción "la iniciación, con conocimiento del interesado, del procedimiento sancionador" (art. 132.2, segundo párrafo), iniciación que se produce "por acuerdo del órgano competente" (art. 11 RD 1398/1993, de 4 de agosto), la LPA no contenía previsión alguna sobre la prescripción de las infracciones administrativas.

Por ello, con anterioridad a la Ley 30/1992 no era preciso para la interrupción del plazo de prescripción la existencia de una resolución formal de incoación y su notificación al interesado sino que, tal como establecía el CP en su art. 114 -actual 132.2

20 Los actores impugnan la sentencia de 29 de octubre de 2001 (JUR 2002, 122253), dictada por la Sala de lo Contencioso-Administrativo (Sección Novena) del TSJ de Madrid, que desestimó el recurso interpuesto contra la sanción que les impuso el Consejo Superior de los Colegios de Arquitectos de España por el uso irregular de sellos de visado del Colegio de Arquitectos de Cantabria. Pues bien, no cabe duda de que la interrupción del plazo de prescripción se produce desde el momento en que tiene lugar la comparecencia de uno de los dos inculpados ante la Junta de Gobierno del Colegio de Cantabria, que le pide explicaciones y ante la que el comparecido devuelve un sello falso. Pues es evidente que ese momento supone ya una actuación encaminada a la averiguación de lo sucedido respecto al uso irregular del sello colegial por los arquitectos afectados, con el añadido de que tal actuación implica por sí misma que los afectados conocen a partir de ese mismo momento que se están efectuando averiguaciones sobre unas graves irregularidades que les afectan a ambos directa y personalmente.

De nuevo aquí, la circunstancia de que no hubiera un acto formal de reanudación del expediente notificado a los afectados no impidió que se produjera la interrupción de la prescripción desde el momento en que el procedimiento se dirigió de nuevo contra los inculpados. En este sentido, sin duda, la remisión de la Sentencia por parte de la Junta de Gobierno a la Comisión de Depuración Profesional el 4 212 a los actores." 
(1995), dicha interrupción se produciría “desde que el procedimiento se dirija contra el culpable", con independencia que ese mismo inicio de las actuaciones fuese conocido por el afectado. Así lo entendía la jurisprudencia de este Tribunal tanto para el ámbito penal como para el administrativo ${ }^{21}$.

Ello no obsta, claro, para que estuviese vedada la indefensión, esto es, que el procedimiento debía ser comunicado al afectado de inmediato al objeto de que este pudiese ejercer todas las medidas que estimase procedentes para su defensa, pero sin que la interrupción de la prescripción estuviese indisolublemente unida al preciso momento de la notificación del comienzo de la actividad de indagación".

Mas del tenor literal de la LPAC y en lógica coherencia con la naturaleza de estas actuaciones que no forman parte del procedimiento sancionador las actuaciones previas no deben tener ninguna incidencia interruptiva de la prescripción de la infracción, toda vez que el art. 132.2 LPAC establece que:

“2. El plazo de prescripción de las infracciones comenzará a contarse desde el día en que la infracción se hubiera cometido.- Interrumpirá la prescripción la iniciación, con conocimiento del interesado, del procedimiento sancionador, reanudándose el plazo de prescripción si el expediente sancionador estuviera paralizado durante más de un mes por causa no imputable al presunto responsable".

En este sentido acertadamente la STSJ Cataluña de 14 de noviembre de 2002 (RJCA 2003 /642), declara que el plazo prescriptivo de la infracción no se interrumpe por unas actuaciones previas con participación de la empresa sancionada ordenadas a determinar si concurrían las circunstancias requeridas para incoar contra la misma expediente sancionador, por cuanto tales actuaciones previas, de naturaleza distinta al ejercicio de la potestad sancionadora, carecen de virtualidad para interrumpir aquel plazo de prescripción.

Sin embargo, hay pronunciamientos jurisprudenciales erróneos a nuestro juicio que desconociendo la naturaleza y finalidad de la información previa hacen depender la posible eficacia interruptiva sobre la acción administrativa para sancionar que pueda tener este trámite de que el afectado tenga o no conocimiento en forma de dicha actuación administrativa. Así en la STS de 26 de noviembre de de 1996 (RAJ 8700), se considera interrumpida la prescripción al exteriorizar la Administración su conducta dirigida a preparar, conocer y en su caso iniciar el expediente sancionador con la práctica de actuaciones previas ante y con conocimiento del interesado ${ }^{22}$.

21 Sentencias de 8 de mayo de 1989 RAJ 4149 y de 9 de julio de 1999 (RAJ 5938) -en materia penal, y de 2 de febrero de 1993 (RJ 1993/659)-, entre otras, en el ámbito administrativo.

22 En este sentido, STS 10 de junio de 1981 (RAJ 2605) en la que el TS proclama: "Que así definido en dos meses el plazo de prescripción de las infracciones perseguidas, su “dies a quo" para el cómputo es obviamente la fecha de comisión de la respectiva falta -art. 114 del C. P.- quedando interrumpido por la dirección del procedimiento contra el supuesto infractor, momento el cual que en la esfera administrativa corresponde identificar con la notificación de apertura o incoación de expediente sancionador prevista 
A sensu contrario, ha entendido en alguna ocasión que no se interrumpe la prescripción si no se produce esa publicidad ante le interesado. En este sentido se niega eficacia interruptiva a las actuaciones previas si no se cumple la doble exigencia de toda actuación administrativa que deba afectar a los interesados, relativa a que toda actuación deba ser notificada y ser reflejada documentalmente en el expediente ${ }^{23}$.

\section{Actuaciones previas y caducidad del procedimiento sancionador}

La caducidad se produce por el transcurso del plazo para resolver a contar desde la fecha del acuerdo de iniciación, según dispone el párrafo 6 del art. 20 RD 1398/1993, precepto éste sobre el que incidió la Ley 4/99 en lo que afecta al artículo 43.4 de la Ley 30/1.992. Tal previsión legal que fija el plazo de caducidad en seis meses desde la iniciación se halla además en consonancia con los apartados 2 y 3 del art. 42 LPAC, que fija el plazo máximo en que debe notificarse la resolución expresa en seis meses a contar, en los procedimientos iniciados de oficio, desde la fecha del acuerdo de iniciación.

No computan, por tanto, dentro de este plazo de caducidad las "actuaciones previas" a la iniciación del procedimiento a que se refiere el art. 12 del RD 1398/1993, tendentes a determinar, con carácter preliminar si concurren las circunstancias que justifiquen la iniciación del procedimiento. Las actuaciones previas no inciden en el cómputo del plazo de caducidad del procedimiento pues cabalmente el dies a quo es el acuerdo de incoación y su notificación.

Asimismo, ha señalado la jurisprudencia que cuando las medidas de carácter provisional preceden a la iniciación del procedimiento sancionador, no constituyen tal inicio, sino que se incorporarán con posterioridad. La posibilidad de adoptar medidas provisionales con anterioridad al acuerdo de iniciación está previsto expresamente en los arts. 72 y 136 LPAC y 15 del RD 1398/1993, de 4 de agosto. De la propia letra e) del art. 15 se puede deducir la posibilidad de que estas medidas provisionales sean anteriores al acuerdo de iniciación. Por consiguiente, ni las fechas de materialización de dichas "actuaciones previas" ni la de la adopción de las "medidas provisionales" son referencias útiles a la hora de determinar el supuesto de hecho del art. 6.2 RD 1398/1993, dado que este precepto se refiere al acuerdo de iniciación ${ }^{24}$. Por ende, una

en el art. 135 ap. 1 de la L. de 17 julio 1958, y momento también de factible anticipación al de comunicación de la apertura de las actuaciones previas a que concierne el art. 134 inciso 2, si de algún modo el inicio de tales diligencias de contenido reservado se hubiese notificado al posible infractor, circunstancia que debe entenderse cumplida cuando aquél previo diligenciamiento comienza en acta inspectora donde con la intervención y firma del interesado o su representante se hace ya constar las presuntas infracciones observadas como así ocurrió en el caso a impulso de los Inspectores del Servicio Nacional de Cereales. Asimismo, para la STS 5 de septiembre de 1988 (RAJ 6701) la práctica de la información reservada a que se refiere el artículo 134-2 de la Ley de Procedimiento Administrativo, interrumpe el plazo de prescripción. 
cosa son las actividades previas al inicio del expediente y otra el inicio del expediente y el precepto, al decir en su apartado $1^{\circ}$ "Cuando de las actuaciones previas..." y en su apartado $2^{\circ}$ "transcurridos dos meses desde la fecha en que se inició el procedimiento", fácilmente se advierte que ese plazo de dos meses desde la fecha de inicio del procedimiento, se está refiriendo, al inicio del procedimiento sancionador, una vez culminadas las actuaciones investigadoras ${ }^{25}$.

El dies a quo de inicio del plazo de caducidad del expediente no puede ser otro que el del acuerdo de incoación del mismo, no el de la denuncia ni la realización de actuaciones previas. En efecto, no puede identificarse el momento de la formulación de la denuncia - que es una de las posibles formas de poner el hecho en conocimiento del órgano con competencia sancionadora, previstas en el art. 11 RD 1398/1993, y al propio tiempo un presupuesto necesario para el inicio del procedimiento sancionador-con el de inicio de dicho procedimiento, olvidando que hasta que no se dicte el acuerdo de incoación, en los términos previstos en el art. 13, no se puede, en puridad, sostener que el mismo se haya iniciado a todos los efectos. Tesis que se ve abonada por la posibilidad de que tal inicio no se produzca, cuando una vez realizadas determinadas actuaciones previas por la Administración, dirigidas a la comprobación de los hechos de la denuncia, se llegue al convencimiento de que no existen razones que justifiquen la incoación del expediente, tal y como determina el art. $12^{26}$. En definitiva, las actuaciones previas pueden venir propiciadas por una denuncia sin que por ello se haya iniciado el procedimiento sancionador propiamente dicho ${ }^{27}$.

Así lo ha vuelto a afirmar recientemente el TS en la sentencia de 17 de marzo de 2009 (RAJ 2009/2848), en la que la parte recurrente invoca que la dilación de la Administración en acordar la iniciación de los expedientes sancionadores motivada por la prosecución de actuaciones preliminares, determinaba adoptar la resolución de archivo de los procedimientos. Señala el TS que el art. 12 del RD 1398/1993, de 4 de agosto, habilita a la Administración a realizar actuaciones previas con anterioridad a la iniciación del procedimiento sancionador, sin que quepa prescindir de dicho trámite en este supuesto, en que la incoación de los expedientes sancionadores se produjo a causa de las denuncias formuladas por diferentes Ayuntamientos, así como diversos colectivos de vecinos contra Endesa Distribución Eléctrica, y con base en informes administrativos, que justificaban una actuación previa de investigación de los servicios provinciales de Industria, Energía y Minas de la Junta de Andalucía, dirigida a comprobar la relación de revisiones periódicas preceptivas de la líneas áreas y centros de transformación realizadas por la compañía eléctrica.

25 STS 21 de marzo de 2000 (RAJ 2724).

26 STSJ Andalucía Granda 27 de enero de 2003 (RJCA 2003 65919).

27 STSJ Andalucía de 24 de septiembre Sala de Sevilla (RJCA 1998/4177) en la que se debate la conformidad a Derecho de la Resolución del Consejero de Cultura de la Junta de Andalucía, de 20 octubre 1995 desestimatoria de los recursos ordinarios deducidos contra las resoluciones sancionadoras dictadas en los Expedientes por la que se sancionaba al actor por utilizar aparatos destinados a la detección de restos arqueológicos sin contar con autorización de la Administración de Cultura (art. 113.5 de la Ley del Patrimonio Histórico Andaluz. 
De lo expuesto, se deduce que "no advertimos que la actuación administrativa de proceder a realizar actuaciones previas haya sido arbitraria, al ejercer la potestad que tiene encomendada para comprobar la realización de hechos relacionados con sus competencias, en relación con la obligación de las empresas distribuidoras de energía eléctrica de asegurar el nivel de calidad y seguridad del servicio de suministro de energía eléctrica, por lo que se revela razonable la respuesta judicial de entender que, a efectos del inicio del cómputo del plazo de caducidad, las fechas que resultan determinantes son las de iniciación de los procedimientos sancionadores, y no las fechas en que se formularon las denuncias o se produjeron las actuaciones administrativas de inspección preliminares" (F.J. Cuarto).

Sin embargo, la jurisprudencia introduce una modulación relativa a la dilación excesiva e injustificada de las actuaciones previas, en cuyo caso ha llegado a apreciar la caducidad del expediente. En este sentido, puede citarse la STSJ Galicia 5 de mayo de 2005 (RJCA 2006/33) que proclama: "a pesar de que la fecha de la infracción había sido la de 16 de febrero de 1998, la primera actividad de investigación de los hechos no se llevó a cabo hasta el día 2 de diciembre de 1999, -casi dos años después- cuando la Delegación de Gobierno de Asturias ofició a la Autoridad Marítima de la localidad costera de Cariño para la identificación del patrón que estaba al mando del buque. Según doctrina de esta Sala, una tardanza tan prolongada e injustificada en la iniciación del expediente, -que se abrió formalmente el 2 de febrero de 2000 - atenta contra los principios más elementales que informan el procedimiento sancionador e invalida, en consecuencia, las sanciones que, en estas circunstancias, hayan podido ser impuestas.

Hay que partir de la base de que el art. 12 del RD 1398/1993, de 4 de agosto aunque admite que, con anterioridad a la iniciación del mismo, se puedan realizar actuaciones previas ... es inaceptable que esa primera fase de investigación y comprobación de lo ocurrido tarde tanto tiempo en comenzarse y haya una demora tan anormal en la investigación de datos tan esenciales, que podían haberse conocido casi de inmediato o en un plazo notablemente inferior al de autos, por lo que, ante esa indudable dejación y manifiesto descuido en su normal tramitación, procede considerar que el procedimiento ha caducado ya en esa fase preliminar con carácter definitivo e insubsanable, sin posibilidad de recobrar virtualidad con esa actividad posterior, ya tan injustificadamente tardía y extemporánea, incompatible con el mínimo de seguridad jurídica exigible en una materia de esta clase".

Por lo demás, la caducidad del expediente no determina la pérdida de valor de las actuaciones previas de comprobación. Así lo ha proclama la jurisprudencia. El que haya caducado el expediente sancionador, no determina la pérdida de valor probatorio de las actuaciones previas de comprobación, que quedan incorporadas, como en el caso de autos, al subsiguiente expediente sancionador incoado por no haber prescrito la infracción muy grave. Los efectos de la caducidad se enmarcan en la pérdida de efectos interruptivos de la prescripción. El TS en la sentencia de 24 de septiembre 216 de 2001 (RAJ 3121) ha afirmado que: esta Sala viene manteniendo (sentencia de 9 de 
mayo de 2001 (RAJ 4248) que el artículo 92.4 de la Ley 30/1992 (al que se remite el art. 44.2 del mismo texto legal) comporta que la caducidad del expediente no impide que sea iniciado de nuevo en tanto no haya prescrito la infracción, pues establece que "La caducidad no producirá por sí sola la prescripción de las acciones del particular o de la Administración, pero los procedimientos caducados no interrumpirán el plazo de prescripción". En el caso examinado las infracciones denunciadas prescriben a los cinco años según el art. 132.2 de la Ley 25/1970, de 2 de diciembre, que aprueba el Estatuto del Vino, de la Viña y los Alcoholes. Ese plazo no había transcurrido desde la comprobación de los hechos hasta que fue reiniciado expediente.

Resulta, por lo demás, evidente que el acuerdo de reiniciar el expediente puede y debe fundarse en los mismos documentos que, con el valor de denuncia (art. 69 de la LAPAC y art. 55.1 del Reglamento del Consejo Regulador de la denominación de origen calificada "Rioja") determinaron la iniciación del expediente caducado. De lo contrario carecería de sentido el mandato legal citado. Por otra parte, la caducidad del expediente no determina la falta de efectos de los actos que tienen valor independiente, como son las Actas e Informes en los que se funda el acuerdo de inicio, respecto del cual se produjeron con anterioridad. Su incorporación al nuevo expediente determina que dichos documentos queden sujetos al régimen y efectos ligados a éste, sin perjuicio de la caducidad del anterior procedimiento y de su falta de efectos en éste ${ }^{28}$.

No obstante, en alguna normativa sectorial se prevé un supuesto particular de caducidad de la acción para la persecución de la infracción. No obstante, en estos casos no estamos en puridad ante un supuesto de caducidad del procedimiento por el transcurso del plazo para resolver y notificar, sino el transcurso del plazo establecido para iniciarlo. Este es el caso de la materia de defensa del consumidor y producción agroalimentaria, en virtud del Real Decreto 1945/1983, de 22 de junio, por el que se regulan las infracciones y sanciones en materia de defensa del consumidor y de la producción agro-alimentaria, cuyo art. 18.2 prevé:

“Caducará la acción para perseguir las infracciones cuando conocida por la Administración la existencia de una infracción y finalizadas las diligencias dirigidas al esclarecimiento de los hechos, hubieran transcurrido seis meses sin que la autoridad competente hubiera ordenado incoar el oportuno procedimiento.

A estos efectos, cuando exista toma de muestras, las actuaciones de la inspección se entenderán finalizadas después de practicado el análisis inicial.

Las solicitudes de análisis contradictorios y dirimentes que fueren necesarios, interrumpirán los plazos de caducidad hasta que se practiquen".

Ha declarado el Tribunal Supremo que el art. 18 del RD 1945/1983 recoge, en su primer apartado, la prescripción de las infracciones a que se refiere el mismo (que fija

28 En el mismo sentido SAN 27 de junio de 2008 (RJCA 2008/ 410), SAN 3 de mayo de 2007 (JUR 2007/210785). 
en cinco años), en su tercer apartado, la caducidad del procedimiento sancionador, y en el segundo, lo que denomina (según la Jurisprudencia impropiamente) "caducidad de la acción", hipótesis esta que es diferente de las otras dos. A estos efectos, cuando exista toma de muestras, las actuaciones de la inspección se entenderán finalizadas después de practicado el análisis inicial". ... y, es doctrina consolidada de la Sala Tercera del Tribunal Supremo la que declara la aplicabilidad a procedimientos sancionadores como el presente de las previsiones que sobre la caducidad se contienen en el ya referido art. 18 del RD 1945/1983 (SSTS 20 de octubre de 1998 (RAJ 9831), 20 de diciembre de 1999 (RAJ 9631) y 4 de julio de 2000 (RAJ 6466). Mas aún, parece oportuno traer a colación la sentencia del Tribunal Supremo de 10 de diciembre de 2001(RAJ 2002 4823), en la que se juzgaban hechos producidos a mediados de 1998 y en la que tras reiterar esa aplicabilidad literalmente se afirma, que "es evidente que transcurridos seis meses desde que la Administración conoce la existencia de una infracción o finalizan, en su caso, las diligencias dirigidas al esclarecimiento de los hechos, sin que por la autoridad competente ordene la incoación del oportuno procedimiento, se produce lo que el precepto reglamentario denomina, impropiamente, "caducidad de la acción", sin perjuicio de lo que establecen los artículos 92.3 y 4 de la Ley 30/1992". Por fin y como tercera precisión de carácter teórico, debe reseñarse que a los efectos de la caducidad de la acción que ahora importa -que en realidad es un plazo de prescripción singularizado porque el día inicial del cómputo viene dado no por la comisión de la infracción sino por el conocimiento de ésta por parte de la Administración-, el dies a quo viene dado por la fecha del análisis inicial, que es cuando se entienden finalizadas las actuaciones de la Inspección (y ello, lógicamente, cuando sea procedente la toma de muestras para comprobar la infracción -véanse las sentencias del Tribunal Supremo 21 de marzo de 1997 (RAJ 2102), y el dies ad quem por la fecha en que se notifica la providencia de incoación del expediente sancionador, criterio este que tras algunas dudas es el hoy mayoritariamente mantenido por la Jurisprudencia (SSTS 5 de marzo de 1990 (RAJ 1859), 23 de marzo 1992 (RAJ 1570), 11 de noviembre de 1996 (RAJ 9163).

Así pues, es doctrina general, salvo ante norma específica de aplicación (STS 3 de julio de 2006 (RAJ 3756) que "el plazo de caducidad debe computarse a partir de la fecha de incoación del expediente sancionador y que, por tanto, queda excluido de dicho cómputo el tiempo anterior a la incoación del procedimiento, esto es, el período durante el que se desarrollan las denominadas actuaciones previas a las que se refiere el art. 12 RD 1398/93 de 4 de agosto. Ahora bien, no cabe ignorar que en el caso de la disciplina deportiva existe una norma específica en cuya virtud, una vez concluidas las fases de control y de comunicación (incardinables en las "actuaciones previas" antes mencionadas), si se aprecian indicios de una posible infracción “...el órgano competente deberá iniciar de oficio el correspondiente expediente disciplinario en un plazo no superior a quince días contados a partir de la recepción en la Federación de la notificación del laboratorio de control antidopaje" (arts. 8 y 9.1 del Real Decreto 255/96, de 16 de febrero, sobre Régimen de Infracciones y Sanciones para la Represión del Dopaje). Existiendo esa norma singular que establece de forma clara e 218 inequívoca el lapso de tiempo en el que debe iniciarse el expediente sancionador, 
tiene razón el recurrente cuando señala que a efectos del cómputo del plazo de caducidad del procedimiento debe tomarse como día inicial no ya la fecha en que efectivamente fue incoado el expediente sancionador, sino aquélla en que debió haberse incoado" 29 .

En definitiva, la fecha constitutiva del dies a quo del plazo de caducidad, de conformidad con el art. 13 de aquel Reglamento es el acuerdo de iniciación de procedimiento sancionador, y la de notificación, pues desde el dictado de dicho acuerdo, la Administración ya está legitimada para realizar actuaciones, entre ellas, sin duda, la adopción de medidas de carácter provisional (art. 13 del Reglamento), antes ya pudo realizar actuaciones previas (art. 12 del Reglamento), sin olvidar que de conformidad con el art. 57.1 de la Ley 30/1992, los actos de las Administraciones Públicas producen efectos desde la fecha en que se dicten. Otra cosa es que la interrupción del plazo de caducidad del procedimiento sancionador por actuación de la Administración precise de la necesidad de la notificación del trámite para que se produzca el efecto interruptivo, "no teniendo virtualidad lo que permanece exclusivamente en el ámbito interno de la Administración", como tiene reconocido una reiterada doctrina jurisprudencial ${ }^{30}$.

\section{CONCLUSIÓN}

Las investigaciones previas o información previa no forman parte del expediente sancionador, no son propiamente expediente administrativo, sino un antecedente que la ley faculta a la Administración para llevar a cabo y a la vista de su resultado acordar lo procedente; esto es, el archivo de las actuaciones o la orden de incoación del expediente. Tienen lugar extramuros del procedimiento sancionador propiamente dicho, cuya finalidad no va más allá de una apreciación acerca de si, efectivamente, se han producido o no los hechos de que se tiene noticia, y, en su caso, personas que hayan intervenido en aquéllos así como las circunstancias concurrentes en la produc-

29 En el caso enjuiciado, el resultado del contra-análisis de la muestra de orina, que confirmaba el resultado del primer análisis, se remitió a la Federación Española de Atletismo el 16 de julio de 1996, según el artículo 9.1 del Real Decreto 255/96 antes citado el expediente debió iniciarse dentro de los quinces días siguientes a esa fecha. Y sin embargo no sucedió tal cosa, pues se decidió recabar un informe del Comité anti-dopaje de la Real Federación Española de Atletismo; y cuando finalmente ese Comité emitió con fecha 13 de diciembre de 1996 el informe que le había sido requerido, tampoco entonces se produjo de manera inmediata la incoación del expediente pues no fue acordada hasta 12 de marzo de 1997 y notificada al interesado el día 19 del mismo mes y año. Por lo que, teniendo en cuenta el singular régimen normativo que antes hemos reseñado debemos concluir que el plazo de caducidad del procedimiento debe computarse desde los quince días (hábiles) siguientes al 16 de julio de 1996, de donde resulta que los plazos determinantes de la caducidad -el de seis meses señalado en el artículo 20.6 del Real Decreto 1398/93 y el adicional de treinta días previsto en el artículo 43.4 de la Ley 30/1992 (redacción originaria)- ya habían transcurrido con exceso cuando se dictó aquella resolución de sobreseimiento de 24 de abril de 1997, y más aún, claro es, cuando se produjo la resolución sancionadora de 10 de octubre de 1997.

30 STSJ de Galicia de 14 de mayo de 1999 (RJCA 1999/1559). 
ción de aquéllos y la intervención de éstas en los mismos, para poder así, concluir si hay motivos razonables para iniciar el procedimiento sancionador.

Constituyen pues, una actuación administrativa preliminar y de carácter contingente que trata de comprobar si "prima facie" puede considerarse que hay una base seria para abrir el procedimiento sancionador propiamente dicho. Cabalmente, la normativa procedimental diferencia, entre ambos tipos de actos administrativos -actuaciones no procedimentales y actuaciones de instrucción del procedimiento- no en razón de su relación temporal con el acto administrativo que, de manera formal, declara abierto el procedimiento, sino por el objeto material de la actuación -determinación de distintos tipos de hechos- en relación con su distinta finalidad -motivar la incoación del procedimiento, en el primer caso, y resolver sobre el procedimiento, en el segundo caso.

EI TC ha afirmado que la información reservada no tiene carácter sancionador, sin perjuicio de que las diligencias practicadas en la información reservada puedan, en su caso, ser valoradas por el órgano decisor. No obstante, aunque las actuaciones previas no constituyen el procedimiento administrativo sancionador, el TC ha reconocido el derecho a no declarar contra sí mismo y a no confesarse culpable como garantías instrumentales del genérico derecho de defensa en esta fase preliminar en la reciente sentencia 142/2009, de 15 de junio. El TC ha extendido la garantía de no autoincriminación propia del procedimiento sancionador a la fase previa o de información reservada, lo que contradice a nuestro juicio tanto el régimen general de estas actuaciones de averiguación como la doctrina del TS. En particular, sobre el derecho del administrado a conocer de estas actuaciones previas y la posible vulneración de su derecho fundamental a no declarar contra sí mismo el TS entiende que el derecho a conocer de la acusación sólo surge cuando el expediente lo permite por haber llegado a un momento en que las imputaciones puedan ya formularse como fundamento sólido.

Mas a continuación, el TC establece una modulación de dicha garantía, fundada en la condición de policías locales de los demandantes de amparo, es decir, en la situación de sujeción especial de la que derivan deberes especiales para con la Administración y con los administrados, ligados a la autoridad de la que están investidos. En definitiva, esta sentencia provoca contradicción con la propia naturaleza de estas actuaciones previas, toda vez que no tienen carácter sancionador sino que mediante las mismas se pretende la averiguación de unos hechos para, en su caso, incoar un expediente disciplinario. Resulta por ello improcedente, la invocación por los recurrentes de los derechos a no declarar contra sí mismos y a no confesarse culpables (art. 24.2CE) puesto que estos derechos se proyectan, exclusivamente, sobre el proceso penal y los procedimientos administrativos sancionadores. 